\title{
Spotlight on eluxadoline for the treatment of patients with irritable bowel syndrome with diarrhea
}

\section{Konstantinos C Fragkos}

Gastrointestinal Services, University College London Hospitals, London, UK
Correspondence: Konstantinos C Fragkos

Gastrointestinal Services, University

College London Hospitals, 250 Euston

Road, London NWI 2PG, UK

Tel +447960 340489

Email constantinos.frangos.09@ucl.ac.uk
This article was published in the following Dove Press journal:

Clinical and Experimental Gastroenterology

25 September 2017

Number of times this article has been viewed

Background: Irritable bowel syndrome with diarrhea (IBS-D) has limited options for treatment currently, including mainly anti-motility medications, antispasmodics, and antidepressants. This review discusses the properties of a new drug, eluxadoline, a gut-targeting mu- and kappa-opioid receptor agonist and a delta-opioid receptor antagonist, and its efficacy and safety in patients with IBS-D.

Materials and methods: A systematic review of the literature was undertaken to identify studies that had investigated eluxadoline as a treatment in IBS-D. A narrative review of other information is provided with respect to pharmacological and chemical properties. Where suitable, meta-analysis was performed with a random-effects model to produce a pooled estimate. Results: Eluxadoline showed efficacy improving stool consistency (standardized mean difference [SMD]: -0.29 at 12 weeks, $p=0.0004 ;-0.46$ at 26 weeks, $p=0.0001$ ), global symptoms (SMD: -0.15 at 12 weeks, $p=0.006 ;-0.14$ at 26 weeks, $p=0.02$ ), quality of life (SMD: 0.21 at 12 weeks, $p<0.0001 ; 0.16$ at 26 weeks, $p=0.007$ ), pain (SMD: -0.17 at 12 weeks, $p=0.001$; -0.16 at 26 weeks, $p=0.01$ ), and adequate relief (odds ratio [OR]: 1.99 at 12 weeks, $p<0.00001$; 1.78 at 26 weeks, $p<0.0001)$. It also improved IBS severity and other abdominal symptoms such as bloating, discomfort, and risk of urgency and fecal incontinence. Its main side effects included constipation (OR: $3.49, p<0.00001$ ), vomiting (OR: $3.42, p=0.0002$ ), abdominal pain (OR: $1.78, p=0.007$ ), and nausea (OR: $1.42, p=0.07$ ). The overall quality of trials was satisfactory with the meta-analyses providing largely homogeneous outcomes.

Conclusion: Eluxadoline's place in clinical practice might prove useful since the pharmacological options of IBS-D are limited and eluxadoline showed a positive effect in treating the symptoms of IBS-D.

Keywords: eluxadoline, irritable bowel syndrome, diarrhea, stool consistency, pain

\section{Plain language summary}

The current review summarizes the benefits of a new drug, eluxadoline, on the symptoms of irritable bowel syndrome with diarrhea in adults. Eluxadoline works on special receptors of the gut slowing the gut transit time. All studies comparing eluxadoline with placebo were searched in the scientific literature. Mathematical analysis of the available studies showed that patients who received eluxadoline had better stool consistency, quality of life, pain, and adequate relief. Patients' irritable bowel syndrome symptoms were less and also less serious. Its main disadvantages were difficulty passing stools, throwing up, feeling sick, and tummy pain. Care should be taken and specialist advice should be sought when using eluxadoline, because it can interact with certain medications and should not be used on patients at risk of pancreatitis. 


\section{Introduction}

Recurrent abdominal pain associated with defecation or a change in bowel habits is considered a functional bowel disorder termed irritable bowel syndrome (IBS) ${ }^{1,2}$ It can present predominantly with diarrhea, constipation, and a mixed or unspecified clinical picture. IBS with diarrhea (IBS-D) is diagnosed when more than $25 \%$ of bowel movements present as Bristol stool form types 6 or 7 and less than $25 \%$ of bowel movements present as Bristol stool form types 1 or 2 (clinically termed diarrhea). ${ }^{3}$ Symptoms should be present during the last 3 months having started at least 6 months before diagnosis. The global prevalence of IBS is around $11 \%,{ }^{4}$ with significant morbidity since up to one-third of people who experience IBS symptoms will consult a physician..$^{5-7}$ Among IBS diagnoses, IBS-D is the most frequent diagnosis (around 40\%). ${ }^{4,8,9}$

IBS is considered a multifactorial disorder with an unknown yet pathophysiological mechanism. ${ }^{10,11}$ Significant attention has been given to variations in visceral hypersensitivity and gastrointestinal motility, with inflammation, alterations in fecal flora, bacterial overgrowth, food sensitivities, genetic predisposition, and psychosocial characteristics having been investigated as contributory factors. ${ }^{12,13}$ Under the biopsychosocial conceptual model for IBS, it is predominantly associated with impaired quality of life (QoL) and increased health care use. ${ }^{14,15}$

Treatment options for IBS-D are essentially few, and national and international bodies recommend as first-step dietary, lifestyle modifications, and psychological interventions along with pharmacological agents, with variable success. ${ }^{16}$ Each treatment approach tackles a different aspect of the pathogenetic mechanism of IBS. Pharmacologically, antidiarrheals (e.g., loperamide), antispasmodics (e.g., mebeverine and hyoscine), tricyclic antidepressants (e.g., amitriptyline) and selective serotonin reuptake inhibitors (e.g., citalopram) have been commonly used. Neomycin, rifaximin, probiotics, alosetron, ramosetron, and ondansetron have shown some effect in certain studies in IBS-D. ${ }^{17-19}$

A new drug in the treatment for patients with IBS-D is eluxadoline (Viberzi ${ }^{\mathrm{TM}}$, Truberzi ${ }^{\mathrm{TM}}$; Allergan Ltd, Dublin, Ireland). It was approved in May 2015 by the US Food and Drug Administration (FDA) and September 2016 by the European Medicines Agency (EMA) as a new agent for IBS-D ${ }^{20}$ and has been recommended as a possible third-line option for IBS-D by the National Institute for Health and Care Excellence (NICE), UK. ${ }^{21}$ In the current paper, we review its efficacy and safety with methods of systematic review and meta-analysis. First, we give a brief overview of eluxadoline's market history, biochemistry, and pharmacology.

\section{Eluxadoline and the gut opioid system}

The endogenous opioid system is composed of cell surface receptors (mu-opioid receptor, delta-opioid receptor, kappa-opioid receptor) and their endogenous ligands (betaendorphin, enkephalins, dynorphins). ${ }^{22}$ Opioid receptors are found within the enteric nervous system in the myenteric and submucosal plexuses, as well as muscular and immune cells in the stomach and intestine, in high concentrations influencing secretory and motor function after the release of the endogenous opioid peptides. ${ }^{23}$ In particular, muopioid receptor agonists promote delay in gastric emptying and small and large intestine transit; increase pyloric tone; induce phasic pressure activity in the pylorus, duodenum, and jejunum; alter the migrating myoelectric complex; and cause an elevation in the resting anal sphincter pressure. . $^{1924,25}$ Hence, mu-opioid receptor agonists (e.g., morphine) promote constipation. Research has shown that delta-opioid receptor antagonists counteract this resulting constipation and increase the analgesia from mu-opioid receptor agonism..$^{22,26,27}$

IBS-D is commonly characterized by pain and diarrhea, and eluxadoline was developed with a view to address both these symptoms. ${ }^{20,28}$ Eluxadoline is an amino acid amide with a molecular weight of $569.65 \mathrm{~g} / \mathrm{mol}$ and a molecular formula of $\mathrm{C}_{32} \mathrm{H}_{35} \mathrm{~N}_{5} \mathrm{O}_{5} ; 5$-[[[(2S)-2-amino-3-[4-(aminocarbonyl)2,6-dimethylphenyl]-1-oxopropyl][(1S)-1-(4-phenyl1H-imidazol-2yl)ethyl]amino]methyl]-2-methoxybenzoic acid (Figure 1).

Eluxadoline is a mu- and kappa-opioid receptor agonist and a delta-opioid receptor antagonist which functions in the gut. ${ }^{19,29-31}$ It has poor oral bioavailability and is used for its local effects at opiate receptors in the gastrointestinal tract. ${ }^{20}$ Eluxadoline is a schedule IV drug in the US, subject to control under the Federal Controlled Substances Act of 1970, in the same class with tramadol and benzodiazepines. ${ }^{20,28}$

The zwitterionic nature of eluxadoline leads it to be negative across the gastrointestinal $\mathrm{pH}$ range leading to poor

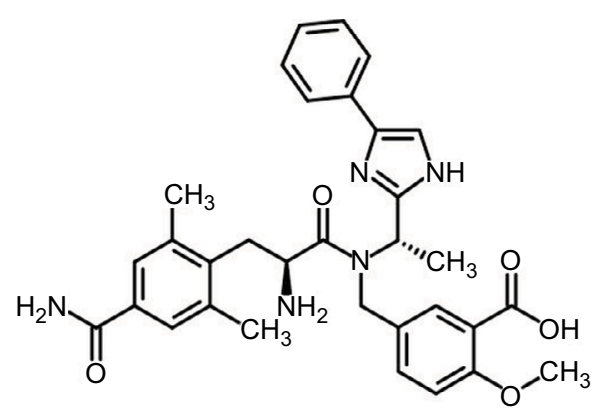

Figure I Chemical structure of eluxadoline. 
oral absorption (1.02\%). Eluxadoline plasma concentrations were very low post oral administration of $100 \mathrm{mg}$ tablets $\left(\mathrm{C}_{\max } \sim 2-4 \mathrm{ng} / \mathrm{mL}\right.$, median time to $\mathrm{C}_{\max }$ was $1.5-2$ hours, irrespective of whether the patient was fed or fasted), ${ }^{20,28}$ and when given with a high-fat meal maximum plasma concentration decreased by $50 \%$. Eluxadoline is mostly excreted in feces $(82 \%)$, and less than $1 \%$ is excreted in urine. The metabolism of eluxadoline involves possibly limited glucuronidation forming an acyl glucuronide metabolite that is then excreted into urine with mean plasma elimination half-life ranging from 3.7 to 6 hours. ${ }^{32}$

Ex vivo and in vivo studies demonstrated that eluxadoline in combination with a delta-opioid receptor antagonist reduced intestinal contractility in isolated guinea pig ileum, decreased neurogenically evoked secretion in mouse small intestine and colon compared with loperamide, and normalized gut transit at 10 - to 20 -fold the minimum effective dose. $^{24,25}$ Other data suggest that delta-opioid receptors play a role in the mechanism of action of eluxadoline possibly mediated through the mu-opioid and delta-opioid heteromer at the level of the myenteric plexus and the longitudinal smooth muscle. ${ }^{33}$ Regarding toxicity, no sign of central nervous system effect was shown with no behavioral changes or signs of withdrawal in monkeys or rats. ${ }^{34}$ With regard to studies in human beings, as part of the drug development program, the abuse potential of eluxadoline compared with placebo and oxycodone has been tested in two studies. ${ }^{34}$ These demonstrated that supratherapeutic doses of oral or intranasal eluxadoline did not result in similar effects as from oxycodone, which was used as a mu-agonist positive control, although eluxadoline was associated with euphoric mood in therapeutic doses.

In vitro studies did not indicate interaction of eluxadoline with cytochrome P450 hepatic enzyme systems, and apart from slow glucuronide metabolite formation found in urine after a $1000 \mathrm{mg}$ dose, eluxadoline does not seem to be metabolized in the liver. ${ }^{32,35}$ The potential for drug-drug interactions with eluxadoline is low. ${ }^{28}$ Metabolic pathways of eluxadoline have not been fully elucidated, and the potential exists for concomitant use of potent CYP inhibitors (e.g., bupropion, ciprofloxacin, clarithromycin, fluconazole, gemfibrozil, and paroxetine) to increase exposure to eluxadoline. As a precautionary measure, patients should be monitored for impairment of mental or physical abilities required for the performance of potentially hazardous tasks (e.g., driving a car and operating machinery) and for other eluxadolinerelated adverse effects. ${ }^{28}$
Eluxadoline is a substrate and inhibitor of the hepatic uptake transporter organic anion transport protein 1B1 (OATP1B1), ${ }^{32}$ and its use is contraindicated in patients receiving potent OATP1B1 inhibitors (e.g., ciclosporin), where a lower dose of eluxadoline is recommended $(75 \mathrm{mg}$ twice per day). Although no dosage adjustment is needed when OATP1B1 substrates (e.g., rosuvastatin) are coadministered with eluxadoline, caution should be exercised in patients receiving high doses of OATP1B1 substrates. The concomitant use of other medications that can cause constipation, such as anticholinergics or 5-hydroxytryptamine $(\mathrm{HT})_{3}$ antagonists, is discouraged because of eluxadoline's potential additive effect. ${ }^{28}$

Eluxadoline is recommended to be taken at $100 \mathrm{mg}$ twice daily with food or $75 \mathrm{mg}$ twice daily with food if the patient has had a cholecystectomy, is being coadministered OATP1B1 inhibitors, or has mild or moderate hepatic impairment or cannot tolerate the higher dose..$^{26,28,36}$ Contraindications for treatment are history of constipation, gastrointestinal obstruction, biliary duct obstruction, sphincter of Oddi dysfunction, alcohol excess, a history of pancreatitis or pancreatic disease, and severe hepatic impairment. ${ }^{26,28,36}$

\section{Clinical effectiveness Methods}

The Preferred Reporting Items for Systematic Reviews and Meta-Analyses (PRISMA) checklist for systematic reviews and meta-analyses was followed. ${ }^{37}$ PubMed/Medline, Scopus, EMBASE, and Cochrane library with no year limits were searched for studies. All randomized controlled trials involving eluxadoline in the treatment of IBS were considered. Exclusion criteria were non-randomized studies, pharmacological studies, and other types of articles (e.g., reviews, letters, and notes). The overall number of studies was 66 which eventually narrowed down to three randomized controlled trials: IBS-2001 (Phase II study), ${ }^{38}$ IBS-3001, and IBS-3002 (two Phase III studies; Figure 2). ${ }^{1,39-41}$ The studies are described in Table 1. The quality of studies (risk of bias) was assessed with Cochrane Collaboration's tool. ${ }^{42} \mathrm{Rev}$ Man software package (Review Manager, Version 5.2; The Cochrane Collaboration, Oxford, UK) was employed for statistical analyses. Dichotomous and continuous data between two groups were estimated with an odds ratio (OR) and the standardized mean difference (SMD) with two-tailed 95\% CI, respectively. SMD values of $0.2,0.5$, and 0.8 were defined as small, moderate, and large effect size, respectively. ${ }^{43}$ Randomeffects meta-analysis was used throughout the current review 



Figure 2 Flowchart of studies.

to account for heterogeneity between studies. The statistic $I^{2}$ was used to quantify the degree of heterogeneity with a score of $25 \%, 50 \%$, and $75 \%$ representing low, moderate, and high levels of inconsistency, respectively. Statistical significance was regarded as $p<0.05$ throughout the study. ${ }^{44}$

\section{Clinical effectiveness analysis} Eluxadoline trials: IBS-200I, IBS-300 I, and IBS-3002

The efficacy and safety of eluxadoline was investigated in one Phase II (IBS-2001) ) $^{38}$ and two Phase III (IBS-3001 and IBS$3002)^{1,39-41}$ randomized controlled trials. The overall number of subjects was 3,235 adults with IBS-D (as defined by Rome III criteria $)^{45}$ participating in large, international, multicenter, placebo-controlled studies. The clinical trials were designed to meet a robust composite end point, defined by the FDA and Committee for Medicinal Products for Human Use (CHMP). Overall, eluxadoline provides an effective and tolerable treatment option in this condition albeit being considered to present a mild-to-moderate effect (as given in the "Methods" section). The outcome measures investigated included: stool consistency, abdominal pain, abdominal bloating, frequency of bowel movements, urgency of bowel movements, severity of symptoms, duration of response to treatment, adverse effects of treatment, and health-related QoL.
IBS-2001 was the first randomized, double-blind, controlled Phase II clinical trial in which 807 patients were assigned to groups who received oral placebo or eluxadoline 5, 25, 100, or $200 \mathrm{mg}$ twice daily for 12 weeks. ${ }^{38}$ The primary end point was the number of composite clinical responses at week 4 , defined by having completed 5-outof-7-days diary entries, and had an improvement by $\geq 30 \%$ and at least 2 points in average daily pain scores as well as a stool consistency score of 3 or 4 on the Bristol Stool Scale for at least $66 \%$ of daily diary entries during that week. ${ }^{35}$ At week 4, more patients receiving treatment with 25 and $200 \mathrm{mg}$ eluxadoline met the primary end point of clinical response when compared with placebo (12\% vs $13.8 \%$ vs $5.7 \%$, respectively; $p<0.05$ ). At week 12 , this effect was sustained with $100 \mathrm{mg}$ eluxadoline, with more clinical responders compared with placebo $(20.2 \%$ vs $11.3 \%$, respectively; $p<0.05$ ). At week 4 , there was a statistically significant increase in the number of stool consistency responders in those taking 25 and $200 \mathrm{mg}$ eluxadoline when compared with placebo ( $16.8 \%$ vs $18.1 \%$ vs $8.2 \%$, respectively; $p<0.05$ ).

Although $200 \mathrm{mg}$ eluxadoline had achieved a significant decrease in IBS Global Symptom Scores compared with placebo by week 4 , which was sustained at weeks 8 and 12 
Table I Randomized controlled trials of eluxadoline for IBS-D

\begin{tabular}{|c|c|c|c|c|}
\hline Design & $\begin{array}{l}\text { Number of } \\
\text { participants }\end{array}$ & Primary and secondary end points & Dose and duration & Inclusion criteria \\
\hline $\begin{array}{l}\text { IBS-200I: } \\
\text { randomized, } \\
\text { double-blind, } \\
\text { placebo-controlled, } \\
\text { multicenter study }{ }^{38}\end{array}$ & $\begin{array}{l}\text { - Total: } 807 \\
\text { - Eluxadoline: } 635 \\
\text { - Placebo: } 172\end{array}$ & $\begin{array}{l}\text { - Primary outcome: number of } \\
\text { composite clinical responses at } \\
\text { week } 4 \text {. A patient was defined as a } \\
\text { clinical responder if they completed } \\
5 \text {-out-of-7-days of diary entries and } \\
\text { met both of the following criteria: an } \\
\text { improvement by } \geq 30 \% \text { and at least } \\
2 \text { points in average daily pain scores as } \\
\text { compared with baseline and achieved } \\
\text { a Bristol Stool Scale score of } 3 \text { or } \\
4 \text { on >66\% of reported days in the } \\
\text { past week } \\
\text { - Secondary outcomes: composite } \\
\text { clinical responders after I } 2 \text { weeks; } \\
\text { abdominal pain responders, stool } \\
\text { consistency responders, adequate } \\
\text { relief responders, frequency of } \\
\text { bowel movements; urgency episodes, } \\
\text { incontinence episodes, changes in IBS } \\
\text { global symptoms, QoL, and severity } \\
\text { scores }\end{array}$ & $\begin{array}{l}\text { Eluxadoline: } 5 \text { or } 25 \\
\text { or } 100 \text { or } 200 \mathrm{mg} \\
\text { twice per day by } \\
\text { mouth vs placebo } \\
\text { twice per day for } \\
12 \text { weeks }\end{array}$ & $\begin{array}{l}\text { - Age: I8-65 years old } \\
\text { - IBS-D defined by Rome III } \\
\text { criteria } \\
\text { - Average of daily pain scores of } \\
\geq 3.0 \text { on a } 0-10 \text {-point scale } \\
\text { - Weekly mean Bristol Stool Scale } \\
\text { score equal to or over } 5.5 \\
\text { - Colonoscopy within the past } \\
5 \text { years for any alarm feature } \\
\text { - Stable diet and no use of rescue } \\
\text { medication within } 14 \text { days of } \\
\text { randomization } \\
\text { - Female patients: postmenopausal } \\
\text { or surgically sterile or abstinent } \\
\text { or receiving contraception, if } \\
\text { sexually active }\end{array}$ \\
\hline $\begin{array}{l}\text { IBS-300I, IBS- } \\
\text { 3002: prospective, } \\
\text { double-blind } \\
\text { placebo-controlled, } \\
\text { multicenter } \\
\text { studies }^{1,39-4 \mid}\end{array}$ & $\begin{array}{l}\text { - Total: } 2428 \\
\text { - Eluxadoline: } 1616 \\
\text { - Placebo: } 809\end{array}$ & $\begin{array}{l}\text { - Primary outcome: number of } \\
\text { composite clinical responders over } \\
26 \text { weeks. Clinical responder: if they } \\
\text { met the daily response criteria for } \\
\text { at least half of the days with diary } \\
\text { entries. On a given day, both of the } \\
\text { below should be satisfied: daily pain } \\
\text { response (worst abdominal pain } \\
\text { scores in the past } 24 \text { hours improved } \\
\text { by } \geq 30 \% \text { compared with baseline) } \\
\text { and daily stool consistency response } \\
\text { (Bristol Stool Scale score < } 5 \text { or the } \\
\text { absence of a bowel movement if } \\
\text { accompanied by } \geq 30 \% \text { improvement in } \\
\text { worst abdominal pain compared with } \\
\text { baseline pain). } \\
\text { - Secondary outcomes: abdominal pain } \\
\text { responders defined as those patients } \\
\text { who met the daily pain response } \\
\text { criteria; stool consistency responders, } \\
\text { adequate relief responders, frequency } \\
\text { of bowel movements; urgency } \\
\text { episodes, incontinence episodes, } \\
\text { changes in IBS global symptoms, and } \\
\text { QoL }\end{array}$ & $\begin{array}{l}\text { Eluxadoline: } 75 \text { or } \\
100 \text { mg twice per day } \\
\text { by mouth vs placebo } \\
\text { twice per day for } \\
26 \text { weeks }\end{array}$ & $\begin{array}{l}\text { - Age: I8- } 80 \text { years old } \\
\text { - IBS-D defined by Rome III } \\
\text { criteria } \\
\text { - Average of worst abdominal pain } \\
\text { scores of } \geq 3.0 \text { on a } 0 \text {-I0-point } \\
\text { scale } \\
\text { - Average mean Bristol Stool } \\
\text { Scale of } \geq 5.5 \text { and at least } 5 \text { days } \\
\text { with a Bristol Stool Consistency } \\
\text { Scale score } \geq 5 \text { on a I-7-point } \\
\text { scale } \\
\text { - Average daily IBS-D Global } \\
\text { Symptom Score of } \geq 2.0 \text { on a } \\
0 \text {-4-point scale } \\
\text { - Stable diet and no use of rescue } \\
\text { medication within I } 4 \text { days of } \\
\text { randomization } \\
\text { - Female patients: postmenopausal } \\
\text { or surgically sterile or abstinent } \\
\text { or receiving contraception, if } \\
\text { sexually active }\end{array}$ \\
\hline
\end{tabular}

Abbreviations: IBS-D, irritable bowel syndrome with diarrhea; QoL, quality of life.

$(-0.26,-0.30,-0.34$, respectively; $p<0.001), 100 \mathrm{mg}$ eluxadoline achieved a similar effect in weeks 8 and $12(-0.19$, -0.26 , respectively; $p<0.05$ ). Similarly, mean differences in IBS Symptom Severity Scores from placebo were statistically significant for the $100 \mathrm{mg}$ eluxadoline group at the end of weeks 4,8 , and $12(-16.69,-33.55,-50.40$, respectively; $p<0.05)$ and for the $200 \mathrm{mg}$ eluxadoline group at weeks 8 and $12(-19.89,-27.48$, respectively; $p<0.05)$. A greater improvement in QoL (IBS-QoL total score) was observed for patients receiving treatment with 100 and $200 \mathrm{mg}$ eluxadoline when compared with placebo at the end of weeks 4, 8, and 12. Adequate relief was achieved in more patients who received 
treatment with 100 or $200 \mathrm{mg}$ eluxadoline at weeks 4,8 , and 12 (69.3\%/67.4\%, 74.9\%/71.5\%, 79.7\%/75.4\%, respectively; $p<0.05$ ), and at week 8 in those receiving $25 \mathrm{mg}$ eluxadoline when compared with placebo $(64.2 \%$ vs $56.8 \%)$. Over the entire study duration, there was a statistically significant increase in the percentage of adequate relief responders in the 100 and $200 \mathrm{mg}$ groups (63.5\% and 59.3\%, respectively) when compared with placebo $(46.4 \% ; p<0.05)$.

Phase III studies included patients who received eluxadoline 100 or $75 \mathrm{mg}$ twice daily, since the $200 \mathrm{mg}$ twice-daily dose did not provide better risk-benefit ratio over the $100 \mathrm{mg}$ dose. ${ }^{38}$ IBS-3001 and IBS-3002 were reported in four papers, inclusive of a pooled analysis. ${ }^{1,39-41}$ They are randomized, double-blind, placebo-controlled, parallel-group, multicenter studies involving overall 2,427 subjects being randomized to compare eluxadoline 75 or $100 \mathrm{mg}$ twice daily and placebo. IBS-3001 was approximately 58 weeks, and IBS-3002 was approximately 34 weeks. A composite clinical response, defined as decrease in daily worst abdominal pain and Bristol Stool Scale scores over 26 weeks, was evaluated. ${ }^{25}$ A patient was defined as a clinical responder if they met the daily response criteria for at least $50 \%$ of the days with diary entries. Treatment with $100 \mathrm{mg}$ eluxadoline resulted in an absolute 9.1-13.7\%-point increase in the proportion of patients achieving the composite primary end point when compared with placebo. ${ }^{21}$ In both IBS-3001 and IBS-3002, a significantly greater proportion of patients receiving $100 \mathrm{mg}$ eluxadoline met the primary end point of clinical response compared with placebo at week $26(29.3 \%$ vs $20.2 \%$ and $32.7 \%$ vs $19.0 \%$, respectively, $p \leq 0.001)$. In IBS-3002, a significantly greater proportion of patients receiving $75 \mathrm{mg}$ eluxadoline achieved a composite response compared with placebo (30.4\% vs $20.2 \%$, respectively, $p<0.05$ ). A similar composite response was found in the pooled analysis with the treatment benefit of eluxadoline over placebo being maintained throughout weeks $1-26 .{ }^{1}$ At week 26, there were significantly more adequate relief responders in those patients receiving $100 \mathrm{mg}$ eluxadoline in both IBS-3001 and IBS-3002 when compared with placebo (49.5\% vs $40.0 \%$ and $53.7 \%$ vs $43.7 \%$, respectively, $p<0.01)$, with a similar pattern in the pooled analysis $(p<0.05)$, while IBS-3002 showed an effect for $75 \mathrm{mg}$ eluxadoline as well, compared with placebo (52.8\% vs $43.7 \%$, respectively, $p=0.013)$. In IBS-3001, IBS-3002, and the pooled analysis, there was a significant increase in stool consistency responders in patients receiving $100 \mathrm{mg}$ eluxadoline throughout weeks $1-26(34.0 \%$ vs $24.1 \%, 39.8 \%$ vs $23.6 \%, 36.8 \%$ vs $23.9 \%$, respectively, $p \leq 0.001)$. IBS-3002 showed a significant effect of $75 \mathrm{mg}$ eluxadoline compared with placebo as well in stool consistency responders $(34.4 \%$ vs $23.6 \%, p<0.001)$.

In IBS-3001 and IBS-3002, there was no significant difference in the proportion of pain responders at 12 and 26 weeks in either eluxadoline groups vs placebo. The pooled analysis however managed to show an effect on pain in the $100 \mathrm{mg}$ eluxadoline group vs placebo $(p<0.05)$, albeit the criteria were slightly more strict. IBS-QoL scores were generally higher in patients receiving 75 or $100 \mathrm{mg}$ eluxadoline when compared with placebo from both studies and their pooled analysis. In a longitudinal analysis, scores were significantly higher than placebo for both eluxadoline treatment groups at each visit in IBS-3001 and in the $75 \mathrm{mg}$ group in IBS-3002, while statistical differences were observed at $4,8,12$, and 18 weeks in the $100 \mathrm{mg}$ group in IBS-3002. In the pooled analysis, IBS-QoL total scores were significantly greater than placebo at week 26 for both the 75 and $100 \mathrm{mg}$ treatment groups $(p<0.001)$. Finally, significant improvements were observed in abdominal bloating, abdominal discomfort, frequency of bowel movements, risk of urgency episodes, and risk of incontinence episodes in patients receiving treatment with eluxadoline compared with placebo.

\section{Meta-analysis}

Meta-analysis was performed on five outcomes at two time points, 12 weeks and 26 weeks: Bristol Stool Scale consistency score, Daily Pain Score, IBS-QoL Total Score, Global Symptom Score, and Adequate Relief of IBS Symptoms. The effects of eluxadoline are statistically significant for all outcomes in favor of eluxadoline, albeit a small-to-moderate effect. There was heterogeneity in the Bristol Stool Scale consistency at 12 weeks and the IBS-QoL at 26 weeks (Table 2 and Figure 3). Quality assessment was satisfactory with no bias present (Figure 4).

\section{Safety and adverse events}

Frequency of any adverse events ranged from $43.8 \%$ to $60.2 \%$ in all trials. Serious adverse events were between $3.0 \%$ and $4.8 \%$, and no deaths were reported during the study. The frequency of adverse events was largely equal between placebo and treatment (Figure 5). Overall, eluxadoline was well tolerated with the most common adverse events being nausea, constipation, vomiting, and abdominal pain seen in patients with IBS-D (frequency less than 10\%). The rate of discontinuation due to constipation and nausea was small and ranged between $0.6 \%$ and $1.7 \%$ for eluxadoline. Five $(0.3 \%)$ patients receiving eluxadoline developed pancreatitis, and there were eight $(0.5 \%)$ cases of abdominal pain with elevated levels of 
Table 2 Meta-analysis of efficacy outcomes and main adverse events

\begin{tabular}{|c|c|c|c|c|}
\hline Outcome & Studies & Participants & Effect estimate $(95 \% \mathrm{CI})$ & Heterogeneity: $I^{2}(\%)$ \\
\hline \multicolumn{5}{|l|}{ Efficacy outcomes } \\
\hline \multicolumn{5}{|c|}{ Bristol Stool Scale consistency score } \\
\hline 12 weeks $^{\mathrm{a}}$ & 3 & 1524 & SMD: $-0.29(-0.45,-0.13)$ & 56 \\
\hline 26 weeks $^{\mathrm{a}}$ & 2 & 1057 & SMD: $-0.42(-0.64,-0.20)$ & 67 \\
\hline \multicolumn{5}{|l|}{ Daily Pain Score } \\
\hline 12 weeks $^{\mathrm{a}}$ & 3 & 1529 & SMD: $-0.17(-0.27,-0.07)$ & 0 \\
\hline 26 weeks $^{\mathrm{a}}$ & 2 & 1060 & SMD: -0.16 (-0.28, -0.04) & 0 \\
\hline \multicolumn{5}{|l|}{ IBS-QoL Total Score } \\
\hline 12 weeks $^{\mathrm{a}}$ & 3 & $|58|$ & SMD: $0.21(0.11,0.31)$ & 10 \\
\hline 26 weeks $^{\mathrm{a}}$ & 2 & 1128 & SMD: $0.16(0.04,0.27)$ & 31 \\
\hline \multicolumn{5}{|c|}{ Global Symptom Score } \\
\hline 12 weeks $^{\mathrm{a}}$ & 2 & 1287 & SMD: $-0.15(-0.27,-0.04)$ & 0 \\
\hline 26 weeks $^{\mathrm{a}}$ & 2 & 1060 & SMD: $-0.14(-0.27,-0.02)$ & 0 \\
\hline \multicolumn{5}{|c|}{ Adequate Relief of IBS Symptoms } \\
\hline 12 weeks $^{\mathrm{b}}$ & 3 & 913 & OR: I.99 (I.6I, 2.45) & 2 \\
\hline 26 weeks $^{\mathrm{b}}$ & 2 & 1060 & OR: I.78 (I.35, 2.35) & 0 \\
\hline \multicolumn{5}{|l|}{ Adverse events } \\
\hline All adverse events ${ }^{c}$ & 2 & 1991 & OR: I.02 $(0.79$, I.32) & 32 \\
\hline Constipation ${ }^{c}$ & 2 & $199 \mid$ & OR: $3.49(2.20,5.55)$ & 0 \\
\hline Vomiting ${ }^{c}$ & 2 & $199 \mid$ & OR: $3.42(1.79,6.54)$ & 0 \\
\hline Abdominal pain ${ }^{c}$ & 2 & $199 \mid$ & OR: I.78 $(1.17,2.70)$ & 0 \\
\hline Nausea $^{c}$ & 2 & 1937 & OR: I.42 $(0.97,2.07)$ & 0 \\
\hline
\end{tabular}

Notes: aSMD (inverse variance random effects). ${ }^{\circ} \mathrm{OR}$ (inverse variance random effects). $\mathrm{C} O \mathrm{R}$ (Mantel-Haenszel random effects).

Abbreviations: IBS, irritable bowel syndrome; OR, odds ratio; QoL, quality of life; SMD, standardized mean difference.

hepatic enzymes in IBS-3001 and IBS-3002. Eight of the 13 cases were associated with spasm in the sphincter of Oddi $(0.5 \%)$. All cases were associated with prior cholecystectomy, and seven cases occurred within 2 weeks of initiated study drug. ${ }^{21}$ Other adverse events are summarized in Table 3 . There was no evidence to suggest biochemical derangement, worsening of IBS symptoms or opioid withdrawal. ${ }^{1,38-41}$

Random-effects meta-analysis of the adverse events indicated that constipation and vomiting were up to 3.5 times more likely to occur with eluxadoline $100 \mathrm{mg}$ compared with placebo. Nausea and abdominal pain were $42 \%$ and $78 \%$, respectively, more likely to occur with eluxadoline $100 \mathrm{mg}$ compared with placebo. Constipation, vomiting, and abdominal pain were significantly higher in the $100 \mathrm{mg}$ eluxadoline group compared with placebo whilst adverse events overall and nausea were not. Significant heterogeneity was not present in any adverse event analyzed.

\section{Discussion and conclusion}

The current review looked at the characteristics of eluxadoline, a gut-targeting mu- and kappa-opioid receptor agonist and a delta-opioid receptor antagonist, and the clinical trials that investigated its efficacy and safety in IBS-D. Overall, eluxadoline is a new molecule with attractive characteristics for the patients with IBS-D, having shown efficacy in improving stool consistency, global symptoms, IBS severity, QoL, pain, and adequate relief. Its main side effects include nausea, vomiting, constipation, and abdominal pain. Precautions should be taken when using it with respect to interaction with certain class of drugs and patients at risk of sphincter of Oddi spasm leading to pancreatitis. The overall quality of trials is satisfactory with the meta-analyses providing largely homogeneous outcomes.

Its place in clinical practice might prove useful since the pharmacological options of IBS-D are limited to loperamide, antispasmodics, and antidepressants. Less commonly used are $5-\mathrm{HT}_{3}$ receptor antagonists, ${ }^{46}$ or rifaximin.${ }^{47}$ The evidence for antidepressants in IBS-D is limited, ${ }^{48}$ while for loperamide or antispasmodics clinical experience is existent and accessibility to them is eased by low cost and over-the-counter purchasing. Clinical use will show whether eluxadoline might prove a suitable second-line treatment for IBS-D instead of antidepressants, or if it will function preferably as third line. A recent NICE UK technology review suggests that eluxadoline can be considered a cost-effective treatment for patients with IBS-D who have not responded adequately to or cannot tolerate other suitable pharmacological therapies. ${ }^{21}$

The current emerging treatments for IBS-D are rifaximin and selective 5-HT ${ }^{3}$ receptors along with existing first-line treatments such as antispasmodics, loperamide, tricyclic 


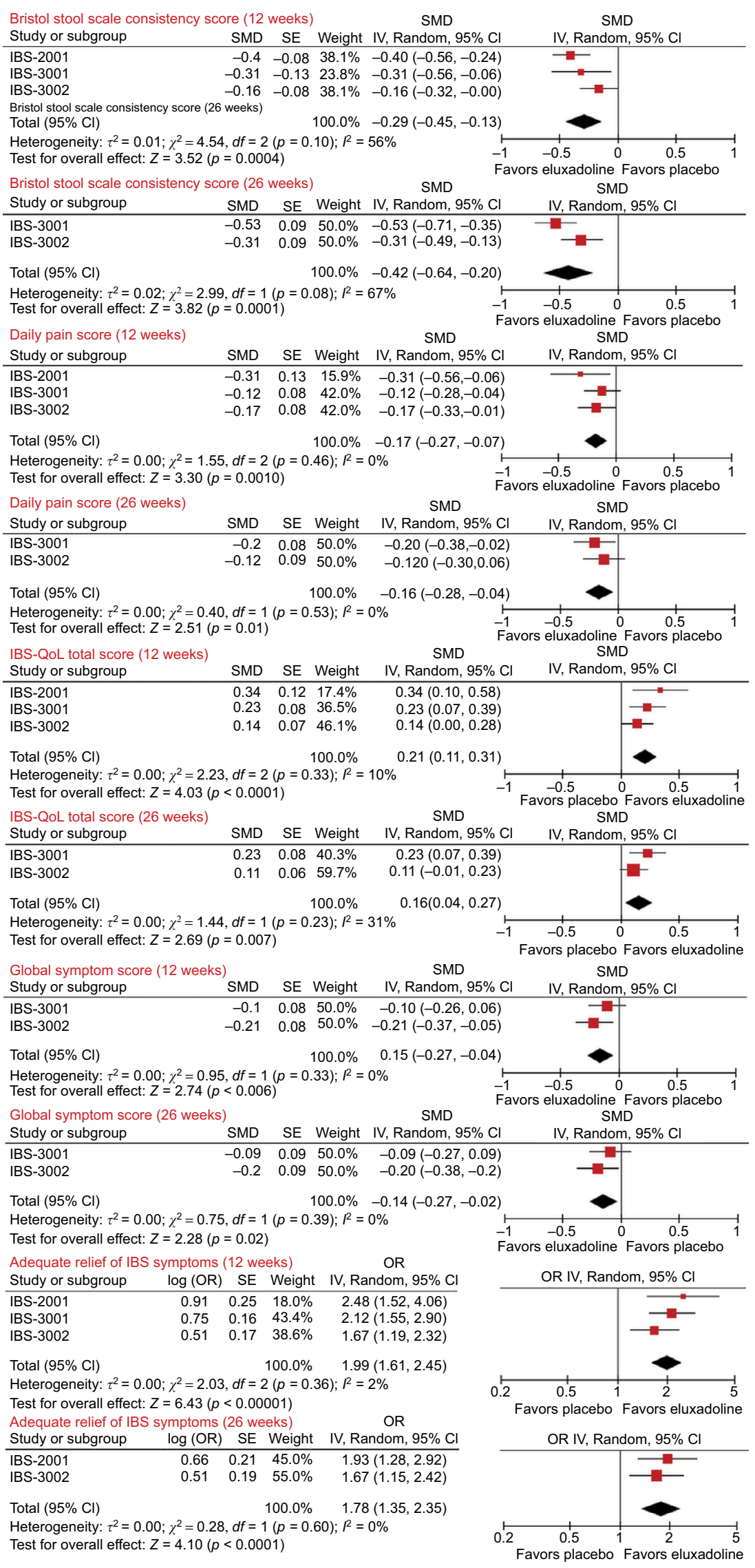

Figure 3 Forest plots of efficacy outcomes.

Note: Eluxadoline vs placebo at 12 and 26 weeks.

Abbreviations: IBS, irritable bowel syndrome; IV, inverse variance; OR, odds ratio; QoL, quality of life; SE, standard error; SMD, standardized mean difference. 




Figure 4 Risk of bias graph: review authors' judgments about each risk of bias item presented as percentages across all included studies.

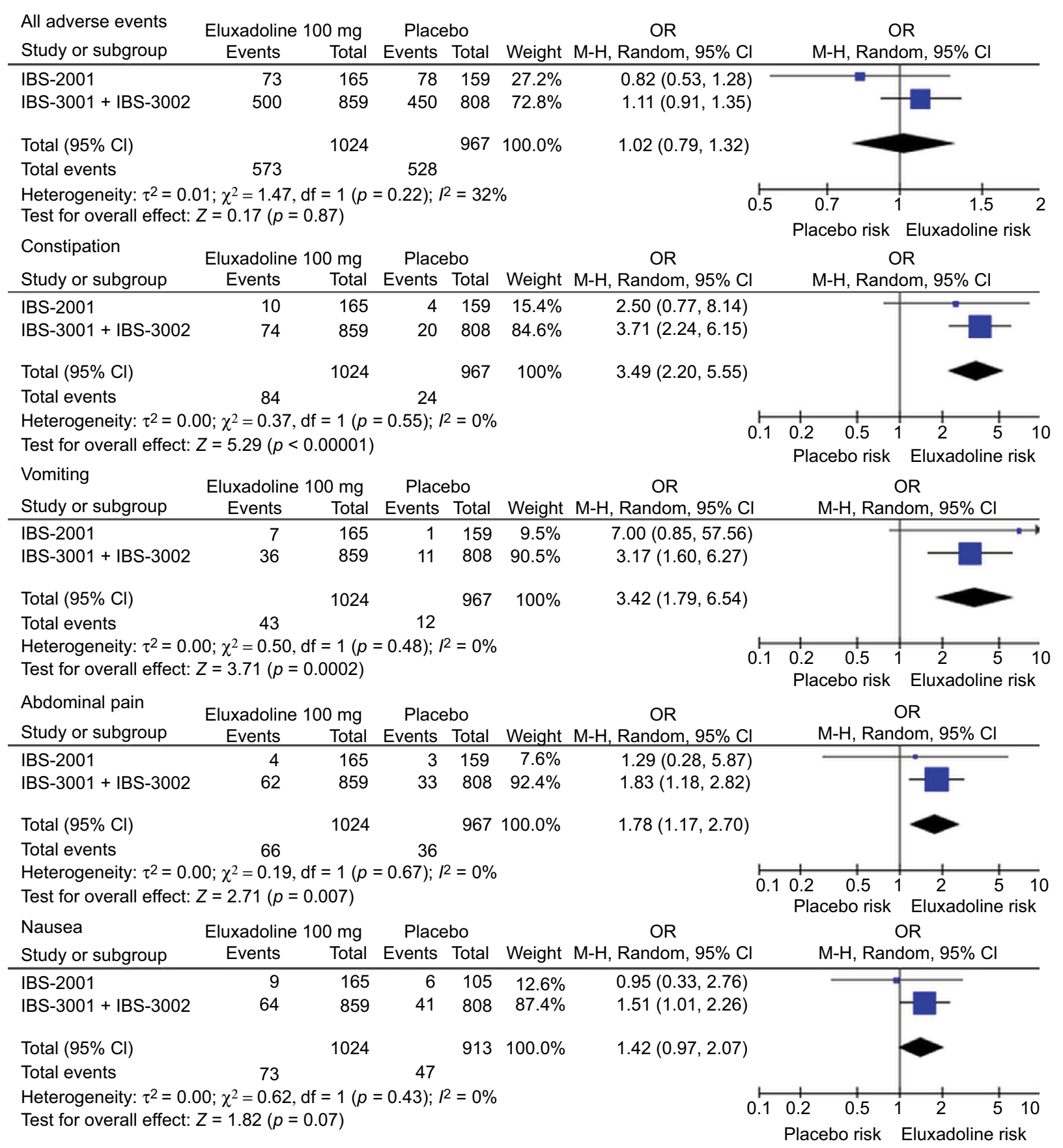

Figure 5 Forest plots of adverse events.

Note: Eluxadoline $100 \mathrm{mg}$ vs placebo.

Abbreviations: M-H, Mantel-Haenszel; OR, odds ratio. 
Table 3 Frequency of adverse events for IBS-200I, IBS-300I, and IBS-3002

\begin{tabular}{|c|c|c|c|c|c|c|c|c|c|}
\hline \multirow[t]{3}{*}{ Adverse events } & \multicolumn{4}{|c|}{ Pooled analysis of IBS-300I and IBS-3002 } & \multicolumn{5}{|l|}{ IBS-200I } \\
\hline & \multicolumn{3}{|c|}{ Eluxadoline } & \multirow{2}{*}{$\begin{array}{l}\text { Placebo } \\
(n=808)\end{array}$} & \multicolumn{4}{|c|}{ Eluxadoline } & \multirow{2}{*}{$\begin{array}{l}\text { Placebo } \\
(n=159)\end{array}$} \\
\hline & $\begin{array}{l}75 \mathrm{mg} \\
(\mathrm{n}=807)\end{array}$ & $\begin{array}{l}100 \mathrm{mg} \\
(\mathrm{n}=859)\end{array}$ & $\begin{array}{l}\text { Combined } \\
\text { groups } \\
(n=1,666)\end{array}$ & & $\begin{array}{l}5 \mathrm{mg} \\
(\mathrm{n}=105)\end{array}$ & $\begin{array}{l}25 \mathrm{mg} \\
(\mathrm{n}=170)\end{array}$ & $\begin{array}{l}100 \mathrm{mg} \\
(\mathrm{n}=165)\end{array}$ & $\begin{array}{l}200 \mathrm{mg} \\
(\mathrm{n}=172)\end{array}$ & \\
\hline All adverse events & $486(60.2)^{\mathrm{a}}$ & $500(58.2)$ & $986(59.2)$ & $450(55.7)$ & $46(43.8)$ & $86(50.6)$ & $73(44.2)$ & $90(52.3)$ & $78(49.1)$ \\
\hline Serious adverse events & $34(4.2)$ & $4 \mid(4.8)$ & $75(4.5)$ & $24(3.0)$ & & & & & \\
\hline Cardiac events & $12(1.5)$ & $17(2.0)$ & $75(4.5)$ & $8(1.0)$ & & & & & \\
\hline Pancreatitis & $2(0.2)$ & $3(0.3)$ & $5(0.3)$ & $0(0.0)$ & & & & & \\
\hline $\begin{array}{l}\text { Spasm of the sphincter of } \\
\text { Oddi }\end{array}$ & $\mathrm{I}(0 . \mathrm{I})$ & $7(0.8)$ & $8(0.5)$ & $0(0.0)$ & & & & & \\
\hline Constipation & $60(7.4)$ & $74(8.6)$ & $134(8.0)$ & $20(2.5)$ & $2(1.9)$ & $5(2.9)$ & $10(6.1)$ & $6(3.5)$ & $4(2.5)$ \\
\hline Nausea & $65(8.1)$ & $64(7.5)$ & $129(7.7)$ & $4 I(5.1)$ & $6(5.7)$ & II (6.5) & $9(5.5)$ & $18(10.5)$ & $7(4.4)$ \\
\hline Abdominal pain & $47(5.8)$ & $62(7.2)$ & $109(6.5)$ & $33(4.1)$ & $3(2.9)$ & $6(3.5)$ & $4(2.4)$ & $13(7.6)$ & $3(1.9)$ \\
\hline Vomiting & $32(4.0)$ & $36(4.2)$ & $68(4.1)$ & II (I.4) & $\mathrm{I}(\mathrm{I} .0)$ & $7(4.1)$ & $7(4.2)$ & $12(7.0)$ & I $(0.6)$ \\
\hline Abdominal distension & $21(2.6)$ & $22(2.6)$ & $43(2.6)$ & $13(1.6)$ & $0(0.0)$ & $0(0.0)$ & $6(3.6)$ & I (0.6) & $2(1.3)$ \\
\hline Gastroenteritis & $36(4.5)$ & $19(2.2)$ & $55(3.3)$ & $27(3.3)$ & & & & & \\
\hline Flatulence & $21(2.6)$ & $27(3.1)$ & $48(2.9)$ & $13(1.6)$ & & & & & \\
\hline $\begin{array}{l}\text { Upper respiratory tract } \\
\text { infection }\end{array}$ & $27(3.3)$ & $47(5.5)$ & $74(4.4)$ & $32(4.0)$ & & & & & \\
\hline Bronchitis & $26(3.2)$ & $27(3.1)$ & $53(3.2)$ & $18(2.2)$ & $4(3.8)$ & $4(2.4)$ & $3(1.8)$ & I (0.6) & $3(1.9)$ \\
\hline Sinusitis & $27(3.3)$ & $24(2.8)$ & $51(3.1)$ & $26(3.2)$ & $5(4.8)$ & $4(2.4)$ & $3(1.8)$ & I (0.6) & $9(5.7)$ \\
\hline Nasopharyngitis & $33(4.1)$ & $23(2,7)$ & $56(3.4)$ & $27(3.3)$ & $4(3.8)$ & $8(4.7)$ & $7(4.2)$ & $6(3.5)$ & $6(3.8)$ \\
\hline Dizziness & $21(2.6)$ & $28(3.3)$ & $49(2.9)$ & $17(2.1)$ & & & & & \\
\hline Anxiety & $10(1.2)$ & $19(2.2)$ & $29(1.7)$ & $14(1.7)$ & & & & & \\
\hline $\begin{array}{l}\text { Increased level of alanine } \\
\text { aminotransferase }\end{array}$ & $17(2.1)$ & $26(3.0)$ & $43(2.6)$ & $12(1.5)$ & & & & & \\
\hline
\end{tabular}

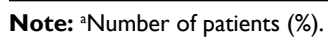

Abbreviation: IBS, irritable bowel syndrome.

antidepressants, and selective serotonin reuptake inhibitors. A statistical comparison of the outcomes for eluxadoline against other treatments is not possible without a network meta-analysis, but a narrative comparison can provide some insight. It has been reported that the number needed to treat for selective serotonin reuptake inhibitors or tricyclic antidepressants was four in IBS-D, ${ }^{49,50}$ which is lower than the number needed to treat for eluxadoline from the current review (9 [95\% CI: 7-13] at 12 weeks, 17 [95\% CI: 11-32] at 26 weeks to achieve adequate relief). Rifaximin is the antibiotic mostly evaluated in studies with patients with IBS. It is an oral, non-absorbable, broad-spectrum antibiotic targeting gut flora and has been shown to relieve IBS symptoms, bloating, abdominal pain, and loose or watery stools better than the placebo for up to 10 weeks after completion of therapy with repeat courses not hindering its durability. ${ }^{51}$ Alosetron and ondansetron as selective $5-\mathrm{HT}^{3}$ receptors have also shown promise in improving stool consistency, improving pain (mainly alosetron), and prolonging gut transit. Compared with eluxadoline, durability was one aspect that was not maintained and declined at 26 weeks while gut transit was not examined or reported in eluxadoline studies.
Despite the statistical significance of the current review's results, caution should be exercised as to how to extrapolate these results to clinically meaningful improvements. The SMDs for pain, QoL, global symptoms score, and stool consistency were generally low to moderate. The most relevant clinical figure of the results is the OR for adequate relief which indicated that almost twice as many responders were in the eluxadoline group, reflecting the numbers needed to treat mentioned earlier. What is apparent is that eluxadoline's response over time declines with regard to almost all symptoms (pain, stool consistency, global symptoms, and adequate relief).

Next, the side effects of eluxadoline are an additional reason that support its use as a third-line treatment. Considering the increased frequency of cholecystectomies in populations, ${ }^{52,53}$ the prospect of acute pancreatitis with consequent hospitalizations is very serious and could deter use. Furthermore, the presence of side effects such as constipation or nausea might well be considered as bad as the original symptoms of IBS-D. Patients might have increased visceral hypersensitivity, and in the context of having failed other treatments already they might be apprehensive trying further medications if they know the high possibility of side effects. 
A final point that needs to be considered is the potential for opioid abuse with eluxadoline as a mu- and kappaopioid receptor agonist. This was shown with the presence of euphoric mood, drunkenness, or sedation, as an adverse event and the general recommendation that patients need to be monitored for their ability to drive a car when on treatment. No other central nervous system side effects were noted outside these events. The data so far however allow a reserved view of eluxadoline as a drug with a low potential for abuse and low risk of dependence, with the US Drug Enforcement Administration (DEA) having ruled that eluxadoline be placed into Schedule IV of the Controlled Substances Act. This is due to the fact that adverse events of euphoric mood were observed with both oral and intranasal eluxadoline at a much lower frequency compared with oxycodone, similar rates of euphoric mood were noted with eluxadoline and placebo and there was also no evidence of opioid withdrawal after discontinuation of eluxadoline. Similarly, the peripheral mu-opioid receptor agonist loperamide showed evidence of limited abuse potential in clinical studies and is not a drug of abuse. ${ }^{54}$ The potential for abuse could stem from the delta-receptor selective antagonism as has been exhibited in mice. ${ }^{34,55,56}$ Pharmacovigilance with prospective follow-up of self-administration or human trials will be required to determine whether eluxadoline is in fact subject to abuse.

In conclusion, considering its affinity to mu-opioid receptors, it is interesting to see whether eluxadoline's use will be investigated in other cases of functional diarrhea such as diabetic diarrhea, opioid withdrawal-induced diarrhea, fecal incontinence, or even high ostomy outputs. The potential for abuse needs to be carefully monitored by clinicians and the pharmaceutical industry. Nevertheless, eluxadoline will hopefully prove successful in filling the treatment gap currently present in IBS-D.

\section{Acknowledgment}

The preparation of this review was not supported by any external funding.

\section{Disclosure}

The author reports no conflicts of interest in this work.

\section{References}

1. Lembo AJ, Lacy BE, Zuckerman MJ, et al. Eluxadoline for irritable bowel syndrome with diarrhea. N Engl J Med. 2016;374(3):242-253.

2. Longstreth GF, Thompson WG, Chey WD, Houghton LA, Mearin F, Spiller RC. Functional bowel disorders. Gastroenterology. 2006;130(5):1480-1491.

3. Mearin F, Lacy BE, Chang L, et al. Bowel disorders. Gastroenterology. 2016;150:1393-1407.
4. Lovell RM, Ford AC. Global prevalence of and risk factors for irritable bowel syndrome: a meta-analysis. Clin Gastroenterol Hepatol. 2012;10(7):712-721.e4.

5. Canavan C, West J, Card T. The epidemiology of irritable bowel syndrome. Clin Epidemiol. 2014;6:71-80.

6. Drossman DA, Patrick DL, Whitehead WE, et al. Further validation of the IBS-QOL: a disease-specific quality-of-life questionnaire. $\mathrm{Am} \mathrm{J}$ Gastroenterol. 2000;95(4):999-1007.

7. Patrick DL, Drossman DA, Frederick IO, DiCesare J, Puder KL. Quality of life in persons with irritable bowel syndrome: development and validation of a new measure. Dig Dis Sci. 1998;43(2):400-411.

8. Endo Y, Shoji T, Fukudo S. Epidemiology of irritable bowel syndrome. Ann Gastroenterol. 2015;28:158-159.

9. Liu J, Hou X. A review of the irritable bowel syndrome investigation on epidemiology, pathogenesis and pathophysiology in China. $J$ Gastroenterol Hepatol. 2011;26(suppl 3):88-93.

10. Camilleri M. Peripheral mechanisms in irritable bowel syndrome. N Engl J Med. 2012;367:1626-1635.

11. Saha L. Irritable bowel syndrome: pathogenesis, diagnosis, treatment, and evidence-based medicine. World J Gastroenterol. 2014;20: 6759-6773.

12. Kellow JE. Pathophysiology and management of irritable bowel syndrome. Korean J Intern Med. 2001;16:137-146.

13. Drossman DA. Functional gastrointestinal disorders: history, pathophysiology, clinical features and Rome IV. Gastroenterology. 2016;150:1262-1279.

14. Van Oudenhove L, Crowell MD, Drossman DA, et al. Biopsychosocial aspects of functional gastrointestinal disorders. Gastroenterology. 2016;150:1355-1367.

15. Francis CY, Morris J, Whorwell PJ. The irritable bowel severity scoring system: a simple method of monitoring irritable bowel syndrome and its progress. Aliment Pharmacol Ther. 1997;11(2):395-402.

16. Fukudo S, Kaneko H, Akiho H, et al. Evidence-based clinical practice guidelines for irritable bowel syndrome. $J$ Gastroenterol. 2015;50(1):11-30.

17. Camilleri M, Katzka DA. Irritable bowel syndrome: methods, mechanisms, and pathophysiology. Genetic epidemiology and pharmacogenetics in irritable bowel syndrome. Am J Physiol Gastrointest Liver Physiol. 2012;302(10):G1075-G1084.

18. Camilleri M, Sellin JH, Barrett KE. Pathophysiology, evaluation, and management of chronic watery diarrhea. Gastroenterology. 2017;152:515-532.e2.

19. Scarpellini E, Laterza L, Ianiro G, Tack J, Abenavoli L, Gasbarrini A. Eluxadoline for the treatment of diarrhoea-predominant irritable bowel syndrome. Expert Opin Pharmacother. 2016;17(10):1395-1402.

20. Garnock-Jones KP. Eluxadoline: first global approval. Drugs. 2015;75(11):1305-1310.

21. NICE [webpage on the Internet]. Irritable Bowel Syndrome (Diarrhoea) - Eluxadoline [ID870] [Internet]; 2017. Available from: https://www. nice.org.uk/guidance/indevelopment/gid-ta10031. Accessed May 20, 2017.

22. Sobczak M, Salaga M, Storr MA, Fichna J. Physiology, signaling, and pharmacology of opioid receptors and their ligands in the gastrointestinal tract: current concepts and future perspectives. J Gastroenterol. 2014;49(1):24-45.

23. Mosinska P, Zielinska M, Fichna J. Expression and physiology of opioid receptors in the gastrointestinal tract. Curr Opin Endocrinol Diabetes Obes. 2016;23(1):3-10.

24. Corsetti M, Whorwell P. Novel pharmacological therapies for irritable bowel syndrome. Expert Rev Gastroenterol Hepatol. 2017;10: $807-815$.

25. Corsetti M, Whorwell P. New therapeutic options for IBS: the role of the first in class mixed micro-opioid receptor agonist and delta-opioid receptor antagonist (mudelta) eluxadoline. Expert Rev Gastroenterol Hepatol. 2017;11:285-292.

26. Kurz A, Sessler DI. Opioid-induced bowel dysfunction: pathophysiology and potential new therapies. Drugs. 2003;63(7):649-671. 
27. Wade PR, Palmer JM, McKenney S, et al. Modulation of gastrointestinal function by MuDelta, a mixed micro opioid receptor agonist/micro opioid receptor antagonist. Br J Pharmacol. 2012;167:1111-1125.

28. Keating GM. Eluxadoline: a review in diarrhoea-predominant irritable bowel syndrome. Drugs. 2017;77(9):1009-1016.

29. Cash BD, Lacy BE, Rao T, Earnest DL. Rifaximin and eluxadoline newly approved treatments for diarrhea-predominant irritable bowel syndrome: what is their role in clinical practice alongside alosetron? Expert Opin Pharmacother. 2016;17(3):311-322.

30. Lacy BE. Emerging treatments in neurogastroenterology: eluxadoline - a new therapeutic option for diarrhea-predominant IBS. Neurogastroenterol Motil. 2016;28(1):26-35.

31. Sobolewska-Wlodarczyk A, Wlodarczyk M, Storr M, Fichna J. Clinical potential of eluxadoline in the treatment of diarrhea-predominant irritable bowel syndrome. Ther Clin Risk Manag. 2016;12:771-775.

32. Davenport JM, Covington P, Bonifacio L, McIntyre G, Venitz J. Effect of uptake transporters OAT3 and OATP1B1 and efflux transporter MRP2 on the pharmacokinetics of eluxadoline. J Clin Pharmacol. 2015;55(5):534-542.

33. Fujita W, Gomes I, Dove LS, Prohaska D, McIntyre G, Devi LA. Molecular characterization of eluxadoline as a potential ligand targeting mu-delta opioid receptor heteromers. Biochem Pharmacol. 2014;92(3):448-456.

34. Levy-Cooperman N, McIntyre G, Bonifacio L, et al. Abuse potential and pharmacodynamic characteristics of oral and intranasal eluxadoline, a mixed mu- and kappa-opioid receptor agonist and delta-opioid receptor antagonist. J Pharmacol Exp Ther. 2016;359:471-481.

35. Rivkin A, Rybalov S. Update on the management of diarrhea-predominant irritable bowel syndrome: focus on rifaximin and eluxadoline. Pharmacotherapy. 2016;36(3):300-316.

36. Eluxadoline (Viberzi) for irritable bowel syndrome with diarrhea. Med Lett Drugs Ther. 2016;58:4-5.

37. Moher D, Liberati A, Tetzlaff J, Altman DG, Group P. Preferred reporting items for systematic reviews and meta-analyses: the PRISMA statement. J Clin Epidemiol. 2009;62:1006-1012.

38. Dove LS, Lembo A, Randall CW, et al. Eluxadoline benefits patients with irritable bowel syndrome with diarrhea in a phase 2 study. Gastroenterology. 2013;145(2):329-338.e1.

39. Cash BD, Lacy BE, Schoenfeld PS, Dove LS, Covington PS. Safety of eluxadoline in patients with irritable bowel syndrome with diarrhea. Am J Gastroenterol. 2017;112(2):365-374.

40. Chey WD, Dove LS, Andrae DA, Covington PS. Early response predicts a sustained response to eluxadoline in patients with irritable bowel syndrome with diarrhoea in two Phase 3 studies. Aliment Pharmacol Ther. 2017;45(10):1319-1328.
41. Lacy BE, Chey WD, Cash BD, Lembo AJ, Dove LS, Covington PS. Eluxadoline efficacy in IBS-D patients who report prior loperamide use. Am J Gastroenterol. 2017;112(6):924-932.

42. Higgins JP, Altman DG, Gotzsche PC, et al. The Cochrane collaboration's tool for assessing risk of bias in randomised trials. BMJ. 2011;343:d5928.

43. Fragkos KC, Zarate-Lopez N, Frangos CC. What about clonidine for diarrhoea? A systematic review and meta-analysis of its effect in humans. Therap Adv Gastroenterol. 2016;9(3):282-301.

44. Fragkos KC, Tsagris M, Frangos CC. Exploring the distribution for the estimator of Rosenthal's "fail-safe' number of unpublished studies in meta-analysis. Commun Stat Theory Methods. 2017;46:5672-5684.

45. Drossman DA. The functional gastrointestinal disorders and the Rome III process. Gastroenterology. 2006;130:1377-1390.

46. Barbara G. Revival of 5-HT3 antagonism as treatment of IBS-D? Gut. 2014;63:1530-1532.

47. Lembo A, Pimentel M, Rao SS, et al. Repeat treatment with rifaximin is safe and effective in patients with diarrhea-predominant irritable bowel syndrome. Gastroenterology. 2016;151(6):1113-1121.

48. Rahimi R, Nikfar S, Rezaie A, Abdollahi M. Efficacy of tricyclic antidepressants in irritable bowel syndrome: a meta-analysis. World $J$ Gastroenterol. 2009;15(13):1548-1553.

49. Foxx-Orenstein AE. New and emerging therapies for the treatment of irritable bowel syndrome: an update for gastroenterologists. Therap $A d v$ Gastroenterol. 2016;9(3):354-375.

50. Ford AC, Moayyedi P, Lacy BE, et al. American College of Gastroenterology monograph on the management of irritable bowel syndrome and chronic idiopathic constipation. Am J Gastroenterol. 2014;109(suppl 1):S2-S26. quiz S7.

51. Pimentel M, Lembo A, Chey WD, et al; TARGET Study Group. Rifaximin therapy for patients with irritable bowel syndrome without constipation. N Engl J Med. 2011;364(1):22-32.

52. Wood R, Fraser LA, Brewster DH, Garden OJ. Epidemiology of gallbladder cancer and trends in cholecystectomy rates in Scotland, 1968-1998. Eur J Cancer. 2003;39(14):2080-2086.

53. Kennedy TM, Jones RH. Epidemiology of cholecystectomy and irritable bowel syndrome in a UK population. Br J Surg. 2000;87(12):1658-1663.

54. Jaffe JH, Kanzler M, Green J. Abuse potential of loperamide. Clin Pharmacol Ther. 1980;28:812-819.

55. Fant RV, Henningfield JE, Cash BD, Dove LS, Covington PS. Eluxadoline demonstrates a lack of abuse potential in phase 2 and 3 studies of patients with irritable bowel syndrome with diarrhea. Clin Gastroenterol Hepatol. 2017;15(7):1021-1029.e6.

56. Chen L, Ilham SJ, Feng B. Pharmacological approach for managing pain in irritable bowel syndrome: a review article. Anesth Pain Med. 2017;7(2):e42747.
Clinical and Experimental Gastroenterology

\section{Publish your work in this journal}

Clinical and Experimental Gastroenterology is an international, peerreviewed, open access, online journal publishing original research, reports, editorials, reviews and commentaries on all aspects of gastroenterology in the clinic and laboratory. This journal is included on PubMed. The manuscript management system is completely online

\section{Dovepress}

and includes a very quick and fair peer-review system, which is all easy to use. Visit http://www.dovepress.com/testimonials.php to read real quotes from published authors. 